\title{
HUBUNGAN ANTARA LATIHAN FISIK DAN KAPASITAS VITAL PARU (KV) SERTA VOLUME EKSPIRASI PAKSA DETIK PERTAMA (VEP1) PADA SISWA PENCAK SILAT PERSAUDARAAN SETIA HATI TERATE DI SUKOHARJO
}

\author{
THE RELATIONSHIP OF PHYSICAL EXERCISE, VITAL CAPACITY (VC) AND \\ FORCED EXPIRATORY VOLUME IN 1 SECOND (FEV) ON THE STUDENTS OF \\ PENCAK SILAT PERSAUDARAAN SETIA HATI TERATE IN SUKOHARJO
}

Sri Wahyu Basuki, Agus Siswanto Jeny

Program Studi Pendidikan Dokter, Fakultas Kedokteran Universitas Muhammadiyah Surakarta Korespondensi: dr. Sri Wahyu Basuki, M. Kes. Email: swb191@ums.id

\begin{abstract}
ABSTRAK
Kapasitas pernapasan penting untuk mengetahui fungsi ventilasi sistem pernapasan. Kapasitas pernapasan yang normal akan mencukupi kebutuhan oksigen sel sehingga metabolism sel optimal. Penelitian ini bertujuan untuk mengetahui hubungan antara lama latihan fisik dan kapasitas vital paru (KV) serta volume ekspirasi paksa detik pertama (VEP1) pada siswa pencak silat Persaudaraan Setia Hati Terate di Sukoharjo. Penelitian ini menggunakan desain penelitian analitik dengan pendekatan cross sectional. Subyek penelitian ini adalah siswa pencak silat Persaudaraan Setia Hati Terate di Sukoharjo. Metode pengambilan sampel secara purposive random sampling. Besar sampel 42 orang yang terdiri atas 21 (50\%) sampel responden dan 21 (50\%) sampel kontrol.. Hasil penelitian diuji dengan uji statistik uji t tidak berpasangan dan Mann Whitney. Hasil penelitian tentang hubungan latihan fisik dan $\mathrm{KV}$ dengan uji analisis diperoleh nilai $\mathrm{P}=0,000$. Hasil penelitian tentang hubungan latihan fisik dan VEP1 dengan uji analisis uji t tidak berpasangan diperoleh nilai $\mathrm{P}=0,000$. Berdasarkan penelitian ini dapat disimpulkan bahwa terdapat hubungan positif yang bermakna antara latihan fisik dan kapasitas vital paru serta volume ekspirasi paksa detik pertama pada siswa pencak silat Persaudaraan Setia Hati Terate di Universitas Muhammadiyah Surakarta.
\end{abstract}

Kata Kunci: KV,VEP1, latihan fisik

ABSTRACT

Respiratory capacity is important to know the function of the respiratory system ventilation. The capacity of the normal breathing oxygen would be sufficient for optimal cell so that the cell metabolism. This study aims to determine the relationship between physical exercise and long lung vital capacity ( $K V)$ and forced expiratory volume in the first second (FEV1) in the martial arts students Faithful Heart Brotherhood Terate in Sukoharjo. This research used analytic study design with cross sectional approach. The subjects of this study were students of martial arts Faithful Heart Brotherhood Terate in Sukoharjo . Purposive sampling method was random sampling . A large sample of 42 people consisting of 21 ( $50 \%$ ) respondents and 21 samples ( $50 \%$ ).. The results of the control samples were tested with statistical test unpaired t test and Mann Whitney with SPSS 16.0. The results of studies on the association of physical exercise and $K V$ values obtained with test analysis $P=0.000$. The results of studies on the association of physical exercise and test FEVI with unpaired t test analysis obtained P value $=0.000$. Based on this study it can be concluded that there is a highly significant positive relationship between physical activity and lung vital capacity and forced expiratory volume in the first second of martial arts students Faithful Heart Brotherhood Terate at Muhammadiyah University of Surakarta .

Keywords: $K V$, FEV1, physical exercise 


\section{PENDAHULUAN}

Kapasitas pernapasan penting untuk mengetahui fungsi ventilasi sistem pernapasan. Kapasitas pernapasan yang normal akan mencukupi kebutuhan oksigen sel sehingga metabolism sel optimal. Salah satu uji faal paru adalah uji spirometri, (Djojodibroto, 2007). Melalui uji spirometri, diperoleh nilai KV dan VEP1. Nilai KV normal kira-kira kira-kira 4 liter. Nilai FEV1 normal kira-kira 3,2 liter. Pemeriksaan dengan spirometer ini penting untuk pengkajian fungsi ventilasi paru secara lebih mendalam. Salah satu factor yang mempengaruhi nilai $\mathrm{KV}$ dan VEP1 adalah latihan (Sheerwood, 2001).

Dengan mencermati adanya hubungan antara latihan fisik dan kapasitas vital paru, penulis ingin mengetahui lebih jauh apakah ada hubungan antara latihan fisik dan kapasitas vital paru serta volume ekspirasi detik pertama pada siswa pencak silat Persaudaraan Setia Hati Terate di Sukoharjo.

Penelitian ini bertujuan Mengetahui hubungan antara latihan fisik dan kapasitas vital paru serta volume ekspirasi detik pertama pada siswa pencak silat Persaudaraan Setia Hati Terate di Sukoharjo.

\section{METODE}

Jenis penelitian ini adalah penelitian observasional (non-experiment) analitik dengan pendekatan cross sectional yang menjelaskan hubungan dua variabel, yaitu variabel bebas (merokok) dan variabel terikat (Volume Ekspirasi Paksa Detik Pertama (VEP1) dan KV (Kapasitas Vital)). Penelitian ini akan dilaksanakan di pencak silat Persaudaraan Setia Hati Terate di Sukoharjo Januari 2014.

Besar sampel penelitian ini adalah 42 orang. Kriteria inklusi (penerima)
a. Siswa pencak silat Persaudaraan Setia Hati Terate di Sukoharjo.
b. Tidak merokok
c. Tidak memiliki riwayat penyakit paru yang menyertai.
d. Bersedia menjadi responden.

Sedang kriteria eksklusi adalah bila sampel melakukan pengulangan pengukuran sebanyak delapan kali tidak menunjukkan hasil yang reproduksibel yaitu didapatkan minimal tiga hasil yang masing-masing nilai variasi perbedaanya kurang dari 5\% atau kurang dari $100 \mathrm{ml}$ untuk nilai VEP1 dan KVP.

Penelitian ini dianalisis menggunakan analisis bivariat, dilakukan dengan mengetahui ada tidaknya pengaruh antara dua variabel melalui uji t tidak berpasangan dan Mann Whitney. Untuk menghitung uji statistik digunakan computer software.

\section{HASIL DAN PEMBAHASAN}

Penelitian tentang hubungan antara latihan fisik dan kapasitas vital paru serta volume ekspirasi paksa detik pertama pada siswa pencak silat Persaudaraan Setia Hati Terate ini telah dilaksanakan di Laboratorium Fisiologi Fakultas Kedokteran Universitas Muhammadiyah Surakarta pada tanggal 18-20 Januari 2014. Besar sampel 42 orang terdiri dari : 21 siswa pencak silat dan 21 orang yang tidak ikut pencak silat.

Tabel 1. Distribusi frequensi sampel yang ikut pencak silat dan tidak ikut pencak silat

\begin{tabular}{ccc}
\hline Variabel & N & Persentase (\%) \\
\hline Ikut pencak silat & 21 & 50,0 \\
Tidak ikut pencak silat & 21 & 50,0 \\
Total & 42 & 100,0 \\
\hline
\end{tabular}

Sumber : data primer

Berdasarkan tabel di atas, dapat diketahui bahwa distribusi frekuensi yang Ikut Pencak Silat dan Tidak Ikut Pencak Silat masing - masing $50 \%$.

Tabel 2. Distribusi nilai mean

\begin{tabular}{ccc}
\hline Variabel & \multicolumn{2}{c}{ Mean } \\
\hline KV & VEP1 \\
\hline Ikut pencak silat & 3292 & 2607 \\
Tidak ikut pencak silat & 2098 & 2091 \\
\hline \multicolumn{2}{c}{ Sumber : data primer }
\end{tabular}

Berdasarkan tabel di atas, dapat diketahui bahwa mean KV dan VEP1 variabel yang ikut pencak silat masing-masing lebih besar daripada variabel yang ikut pencak silat. 
Tabel 3. Uji normalitas data

\begin{tabular}{cccc}
\hline \multirow{2}{*}{ Komponen } & \multicolumn{2}{c}{ Shapiro-Wilk } \\
\cline { 3 - 4 } & & $\mathrm{N}$ & $p$ value \\
\hline \multirow{2}{*}{ KV } & Ikut pencak silat & 21 & 0,639 \\
& Tidak ikut pencak silat & 21 & 0,035 \\
\multirow{2}{*}{ VEP1 } & Ikut pencak silat & 21 & 0,412 \\
& Tidak ikut pencak silat & 21 & 0,861 \\
\hline
\end{tabular}

Sumber : data primer

Uji normalitas yang digunakan adalah uji Shapiro-wilk karena sampel pada penelitian ini masing-masing variabel sebanyak 21 sampel (kurang dari 50 sampel). Berdasarkan tabel diatas, hasil uji normalitas data $\mathrm{KV}$ yang ikut pencak silat diperoleh nilai $p>0,05$, sedangkan data KV yang tidak ikut pencak silat diperoleh nilai $\mathrm{p}<0,05$. Oleh karena itu untuk mengetahui hubungan antara yang ikut pencak silat dan tidak ikut pencak silat dipakai uji alternatif dari uji t tidak berpasangan yaitu uji Mann- Whitney karena syarat untuk menggunakan uji t tidak berpasangan tidak terpenuhi (Dahlan, 2009).
Adapun hasil uji normalitas data VEP1 baik yang ikut pencak silat maupun yang tidak ikut pencak silat diperoleh $p>0,05$, Oleh karena itu untuk mengetahui hubungan antara VEP1 antara ikut pencak silat dan tidak ikut pencak silat digunakan uji t tidak berpasangan (Dahlan, 2009).

Tabel 4. Deskripsi hasil uji Mann-Whitney

\begin{tabular}{cccc}
\hline Kapasitas vital & $\mathbf{N}$ & $\mathbf{P}$ & Keterangan \\
\hline $\begin{array}{c}\text { Yang ikut pencak } \\
\text { silat }\end{array}$ & 21 & 0,000 & Sangat bermakna \\
$\begin{array}{c}\text { Tidak ikut pencak } \\
\text { silat }\end{array}$ & 21 & \\
\hline \multicolumn{3}{c}{ Sumber : data primer }
\end{tabular}

Berdasarkan tabel di atas, diperoleh nilai $\mathrm{p}$ $=0,000$. Oleh karena nilai $\mathrm{p}<0,001$ menunjukkan bahwa adanya hubungan yang sangat bermakna antara latihan fisik dan kapasitas vital paru pada siswa pencak silat.

Tabel 5. Deskripsi hasil T test independent

\begin{tabular}{llccc}
\hline & komponen & \multicolumn{1}{c}{ p } & Keterangan \\
\hline VEP1 & Levene's test & T test independent & \\
& Yang ikut pencak silat & 0,87 & 0,000 & Sangat bermakna \\
& Tidak ikut pencak silat & & & \\
\hline
\end{tabular}

Sumber : data primer

Berdasarkan tabel di atas, diperoleh nilai $\mathrm{p}$ pada Levene's test $>0,05$. Oleh karena hasil uji $\mathrm{T}$ yang digunakan adalah Equal variances assumed , diperoleh nilai $\mathrm{p}<0,001$ menunjukkan bahwa adanya hubungan yang sangat bermakna antara latihan fisik dan VEP1 pada siswa pencak silat.

Berdasarkan hasil analisis dengan menggunakan uji Mann-Whitney dan $T$ test independent didapatkan nilai $\mathrm{p}=0,000$. Oleh karena nilai $\mathrm{p}<0,001$ menunjukkan bahwa adanya hubungan yang sangat bermakna antara latihan fisik dan KV serta VEP1 pada siswa pencak silat.

Orang yang terlatih dengan latihan fisik, jika melakukan kegiatan mempunyai kemampuan untuk menghisap udara lebih banyak dan dalam periode waktu yang lebih lama, juga mampu menghembuskan keluar sisa-sisa pembakaran lebih banyak, sebab otot-otot di sekeliling paruparunya telah terlatih untuk melakukan kerja lebih banyak (Cooper, 1983).
Ketika melakukan aktivitas fisik, otot memerlukan suplai energi yang lancar dan stabil, sehingga diperlukan oksigen sebagai bahan bakar pembentukan energi secara adekuat. Cara untuk mencukupi kebutuhan oksigen dengan meningkatkan frekuensi respirasi sehingga pada seseorang yang beraktifitas akan terjadi efisiensi ventilasi yang menyebabkan kapasitas vital paru dapat meningkat sehingga dapat disimpulkan bahwa kapasitas vital paru memiliki hubungan secara langsung terhadap latihan fisik.

Fox (2003) menyatakan bahwa ketika kadar hemoglobin berada di bawah normal, maka jumlah oksigen dalam darah juga lebih rendah begitupula sebaliknya. Semakin tinggi kadar hemoglobin, proses transportasi oksigen ke jaringan akan semakin optimal. Kadar hemoglobin pada penelitian ini tidak dilakukan.

Selain ditentukan oleh sistem respirasi, kardiovaskular, transportasi oksigen, dan 
biokimiawi, kapasitas vital paru juga dipengaruhi oleh intensitas latihan fisik. Willmore dan Costill (1994) mengatakan bahwa latihan fisik yang intens dapat meningkatkan $\geq 20 \%$. Latihan fisik selain dapat mempengaruhi nilai kapasitas vital paru juga dapat mempengaruhi nilai VO 2 maks paru seseorang.

Penelitian Widiastuti (2009) menunjukkan dari 26 sampel, $22(86,4 \%)$ sampel yang mengkonsumsi energi sesuai dengan kebutuhan dan memiliki nilai kapasitas vital paru yang telah memenuhi standar, sisanya sebanyak $4 \quad(15,4 \%)$ sampel mengkonsumsi energi kurang dari kebutuhan memiliki nilai kapasitas vital paru kurang dari standar.

Dalam penelitian ini terdapat keterbatasan yang menyebabkan hasil penelitian tidak dapat digeneralisasikan pada populasi umum karena penelitian ini hanya dilakukan di Laboratorium
Fisiologi Kedokteran Universitas Muhammadiyah Surakarta. Juga adanya keterbatasan dan pengukuran pada penelitian ini sehingga menyebabkan kurangnya waktu dan ketelitian dalam penelitian.

\section{SIMPULAN DAN SARAN}

Terdapat hubungan positif yang sangat bermakna antara latihan fisik dan kapasitas vital paru serta volume ekspirasi paksa detik pertama pada siswa pencak silat Persaudaraan Setia Hati Terate di Universitas Muhammadiyah Surakarta, nilai $\mathrm{p}<0,001$. Peneliti selanjutnya yang tertarik untuk meneliti hubungan antara latihan fisik dan kapasitas vital paru serta volume ekspirasi paksa detik pertama dapat memperluas dan mencari faktor-faktor yang mempengaruhi hubungan antara latihan fisik dan kapasitas vital paru lebih banyak lagi.

\section{DAFTAR PUSTAKA}

Cooper KH. 1983. Aerobik.Cetakan kelima.PT. Gramedia. Jakarta.

Dahlan, M. S. 2009. Besar Sampel dan Cara Pengambilan Sampel. Jakarta : Salemba Medika.

Dahlan, M. S. 2009. Statistik untuk Kedokteran dan Kesehatan. Jakarta : Salemba Medika.

Djojodibroto, D. 2009. Respirologi (Respiratory Medicine). Jakarta: EGC

Fox, S. I. 2003. Muscle :Mechanism of Contraction and Neural Control. In : Fox

SI. Human Physiology, 8nd ed. Kota : McGraw-Hill; p. 343.

Sherwood, LI. 2001. Fisiologi Manusia. Jakarta : EGC.

Widiastuti PA, Kushartanti BMW, Kandarina IBJ. Pola makan dan kebugaran jasmani atlet pencak silat selama pelatihan daerah pekan olahraga nasional XVII Provinsi Bali 2008.2009. Jurnal Gizi Klinik Indonesia.

Wilmore, H.J., and Costill, DL., 1994. Physiology of Sport And Exercise, USA: Human Kinetics, Champaign. 